Biogeosciences, 6, 15-23, 2009

www.biogeosciences.net/6/15/2009/

(c) Author(s) 2009. This work is distributed under

the Creative Commons Attribution 3.0 License.

\title{
Vertical structure and diurnal variability of ammonia exchange potential within an intensively managed grass canopy
}

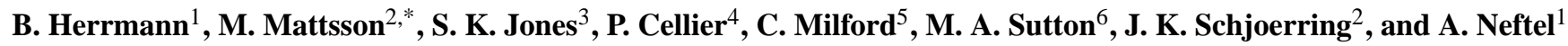 \\ ${ }^{1}$ Agroscope Reckenholz-Tänikon Research Station ART, Reckenholzstrasse 191, 8046 Zürich, Switzerland \\ ${ }^{2}$ Plant and Soil Science Laboratory, University of Copenhagen, Faculty of Life Sciences, Thorvaldsensvej 40, \\ 1871 Frederiksberg C, Copenhagen, Denmark \\ ${ }^{3}$ Scottish Agricultural College, King's Buildings, West Mains Road, Edinburgh EH9 3JG, UK \\ ${ }^{4}$ Inst. National de la Recherche Agronomique (INRA), UMR Environnement et Grandes Cultures, Thiverval-Grignon, France \\ ${ }^{5}$ Institute of Earth Sciences "Jaume Almera", CSIC, Lluis Solé I Sabaris, 08028, Barcelona, Spain \\ ${ }^{6}$ Natural Environmental Research Council, Centre for Ecology and Hydrology, Edinburgh Research Station, \\ Penicuik EH26 0QB, Midlothian, UK \\ *now at: Section for Economy and Technology, Halmstad University, Halmstad, 30118, Sweden
}

Received: 13 May 2008 - Published in Biogeosciences Discuss.: 15 July 2008

Revised: 17 November 2008 - Accepted: 17 November 2008 - Published: 6 January 2009

\begin{abstract}
Stomatal ammonia compensation points $\left(\chi_{s}\right)$ of grass species on a mixed fertilized grassland were determined by measurements of apoplastic $\left[\mathrm{NH}_{4}^{+}\right]$and $\left[\mathrm{H}^{+}\right]$in the field. Calculated $\chi_{s}$ values were compared with in-canopy atmospheric $\mathrm{NH}_{3}$ concentration $\left(\chi_{a}\right)$ measurements.

Leaf apoplastic $\left[\mathrm{NH}_{4}^{+}\right]$increased by a factor of two from the lowest level in the canopy to the top level. Bulk leaf $\left[\mathrm{NH}_{4}^{+}\right]$and especially $\left[\mathrm{NO}_{3}^{-}\right]$slightly increased at the bottom of the canopy and these concentrations were very high in senescent plant litter. Calculated $\chi_{s}$ values were below atmospheric $\chi_{a}$ at all canopy levels measured, indicating that the grassland was characterized by $\mathrm{NH}_{3}$ deposition before cutting. This was confirmed by the $\chi_{a}$ profile, showing the lowest $\chi_{a}$ close to the ground $(15 \mathrm{~cm}$ above soil surface) and an increase in $\chi_{a}$ with canopy height. Neither $\chi_{s}$ nor $\chi_{a}$ could be measured close to the soil surface, however, the $\left[\mathrm{NH}_{4}^{+}\right]$in the litter material indicated a high potential for $\mathrm{NH}_{3}$ emission.
\end{abstract}

A diurnal course in apoplastic $\left[\mathrm{NH}_{4}^{+}\right]$was seen in the regrowing grass growing after cutting, with highest concentration around noon. Both apoplastic and tissue $\left[\mathrm{NH}_{4}^{+}\right]$increased in young grass compared to tall grass. Following

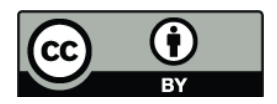

Correspondence to: A. Neftel

(albrecht.neftel@art.admin.ch) cutting, in-canopy gradients of atmospheric $\chi_{a}$ showed $\mathrm{NH}_{3}$ emission but since calculated $\chi_{s}$ values of the cut grass were still lower than atmospheric $\mathrm{NH}_{3}$ concentrations, the emissions could not entirely be explained by stomatal $\mathrm{NH}_{3}$ loss. High tissue $\left[\mathrm{NH}_{4}^{+}\right]$in the senescent plant material indicated that this fraction constituted an $\mathrm{NH}_{3}$ source. After fertilization, $\left[\mathrm{NH}_{4}^{+}\right]$increased both in apoplast and leaf tissue with the most pronounced increase in the former compared to the latter. The diurnal pattern in apoplastic $\left[\mathrm{NH}_{4}^{+}\right]$was even more pronounced after fertilization and calculated $\chi_{s}$ values were generally higher, but remained below atmospheric $\left[\mathrm{NH}_{3}\right]$.

\section{Introduction}

Several investigations have revealed the bidirectional character of $\mathrm{NH}_{3}$ exchange between vegetation and the atmosphere with large fluctuations on annual, seasonal and daily time scales (Sutton et al., 1995, 2007; Bussink et al., 1996; Herrmann et al., 2001; Horvath et al., 2005; Walker et al., 2006). In a non-fertilized managed grassland in The Netherlands, $\mathrm{NH}_{3}$ emission fluxes were frequent (about $50 \%$ of the time) during a warm and dry summer period, while in a wet and cool autumn period deposition fluxes dominated ( $80 \%$ of the time; Kruit et al., 2007).

Published by Copernicus Publications on behalf of the European Geosciences Union. 
The direction of the $\mathrm{NH}_{3}$ flux between plant leaves and the atmosphere depends mainly on the stomatal $\mathrm{NH}_{3}$ compensation point $\left(\chi_{s}\right)$ of leaves, which is the atmospheric $\mathrm{NH}_{3}$ concentration where $\mathrm{NH}_{3}$ emission and deposition are balanced and no net exchange occurs (Farquhar et al., 1980; Husted et al., 1996). On the canopy level the apparent compensation point will also be influence by all other surfaces (soil, leave litter) and will depend on the $\mathrm{pH}$ of these surfaces (Burkhardt et al., 2008; Flechard et al., 1999)

In chamber studies $\chi_{s}$ was shown to be influenced by the $N$ status of the plant (Sharpe and Harper, 1995; Mattsson et al., 1998; Mattsson and Schjoerring, 2002; Sommer et al., 2004) and by environmental factors such as temperature (Mattsson et al., 1997), photosynthetic photon flux density and air humidity (Mattsson and Schjoerring, 1996; Husted and Schjoerring, 1996; Husted et al., 2002).

Measurements of vertical $\mathrm{NH}_{3}$ concentration gradients within a grass/clover canopy (Denmead et al., 1976) and a quackgrass (Agropyron repens L.) canopy (Lemon and van Houtte, 1980) showed a sharp increase of the $\mathrm{NH}_{3}$ concentration towards the soil surface, resulting in a upward $\mathrm{NH}_{3}$ flux from the soil to the base of the grass canopy. Similarly, a more recent study based on the inverse Lagrangian source/sink analysis for an oilseed rape (Brassica napus) canopy also revealed highest $\mathrm{NH}_{3}$ concentrations at the ground level, which was suggested to originate from decomposing litter leaves (Nemitz et al., 2000). This was supported by a very high ammonium $\left(\mathrm{NH}_{4}^{+}\right)$concentration measured in senescent plant material from oilseed rape compared to the concentration in intact leaves (Husted et al., 2000). It is not known whether corresponding $\mathrm{NH}_{4}^{+}$gradients between leaves of different age may occur in perennial grass species.

A diurnal pattern of the $\mathrm{NH}_{3}$ exchange has been observed in Brassica napus (Husted et al., 2000), barley (Schjoerring et al., 1993) and grassland (Trebs, et al. 2006), with highest $\mathrm{NH}_{3}$ emission rates typically occurring during the daytime and low rates at night. Reported diurnal variations in apoplastic $\mathrm{NH}_{4}^{+}$and $\mathrm{H}^{+}$concentrations are small (Husted et al., 2000; van Hove et al., 2002). Consequently changes in $\mathrm{NH}_{3}$ emission were attributed to temperature effects on $\mathrm{NH}_{3}$ solubility and $\mathrm{NH}_{4}^{+}$dissociation in the apoplast due to varying canopy temperature during the diurnal course (Husted and Schjoerring, 1996). In addition, fluctuations in leaf surface wetness will affect the $\mathrm{NH}_{3}$ exchange (Walker et al., 2006; Kruit et al., 2007). Diurnal variations of $\mathrm{NH}_{3}$ emission have also been observed over grassland, but correlation between the measured atmospheric $\chi_{a}$ and $\chi_{s}$, calculated from flux density measurements, was low (Harper et al., 1996).

The experiment presented here was carried out in May and June 2000 in Braunschweig, Germany and was part of a joint investigation within the EU GRAMINAE project (for a detailed description of the experiment see Sutton et al., 2008). The aim was to estimate the $\mathrm{NH}_{3}$ exchange potential of the vegetation on a vertical gradient within a fertilized grass canopy and its diurnal variations by means of $\chi_{s}$ mea- surements. The vacuum infiltration technique for apoplast extraction was directly applied in the field and calculated $\chi_{s}$ was related to in-canopy $\mathrm{NH}_{3}$ concentrations. It is discussed whether leaf bulk tissue $\left[\mathrm{NH}_{4}^{+}\right]$could be a useful indicator of $\chi_{s}$, since measuring this parameter would be more convenient and less time-consuming than the determination of $\chi_{s}$.

A priori knowledge of $\chi_{s}$ or a simple parameterisation of it is important for modelling $\mathrm{NH}_{3}$ exchange in ecosystem models using the canopy compensation concept.

\section{Materials and methods}

\subsection{Description and management of the measurement site}

The measurement site was located near Braunschweig $\left(52^{\circ} 18^{\prime} \mathrm{N}, 10^{\circ} 26^{\prime} \mathrm{E}, 79 \mathrm{~m}\right.$ a.s.l.) in Lower Saxony, Germany. The field was $600 \times 300 \mathrm{~m}$ in size and consisted of a mixed sward dominated by Lolium perenne $\mathrm{L}$. It has been an intensively managed grassland for 4 years, typically receiving $250 \mathrm{~kg} \mathrm{Nha}^{-1} \mathrm{a}^{-1}$. Prevailing wind directions were SW to $\mathrm{W}$ and E. A farm with 300 cattle and 3000 pigs was located in the $\mathrm{W}$ of the field. The field was cut on 29 May and $\mathrm{N}$ fertilizer $\left(100 \mathrm{~kg} \mathrm{~N} \mathrm{ha}^{-1}\right)$ was applied as calcium ammonium nitrate on 5 June.

\section{$2.2 \mathrm{NH}_{3}$ concentration measurements}

Instruments for the measurement of $\chi_{a}$ were placed in the centre of the field. $\chi_{a}$ was measured continuously on-line by Mini Wet Effluent Denuders (mini-WEDD), as described by Neftel et al. (1998), connected to a four-channel fluorescent analyzer. Before cutting three of the Mini-WEDDs were placed within the plant canopy and one directly above the canopy. Air flow rates of $200 \mathrm{ml} \mathrm{min}^{-1}$ and $800 \mathrm{ml} \mathrm{min}^{-1}$ were used for the lowest two mini-WEDDs and for the two above, respectively. A liquid flow of $0.12 \mathrm{ml} \mathrm{min}^{-1}$ was used and the detection limit was $0.1 \mu \mathrm{g} \mathrm{NH}_{3} \mathrm{~m}^{-3}$.

\subsection{Sampling of plant material}

During the first period of the experiment, a few days before the field was cut on 24 and 25 May, plant material was collected from different layers within the plant canopy and separated into flowers, stems and leaf sheaths and green and brown leaf laminae.

The samples for the analysis of the diurnal variation have been taken on the 26 May, while samples for the in canopy profiles have been taken on the 29 May in an uncut small plots. The cut of the whole field took place in the morning of the 29 May.

The fully developed green leaf laminae were used for apoplast extraction as described below. After the cut it was no longer possible to properly divide plant material into different species. Therefore a mixture of cut leaves from all 
the species was collected. The plant material was randomly collected in the field and immediately brought to an adjacent field lab. Some of the leaves were used for extraction directly after sampling and the plant material used for the determination of tissue $\mathrm{NH}_{4}^{+}$and $\mathrm{NO}_{3}^{-}$was immediately frozen in liquid nitrogen and stored at $-20^{\circ} \mathrm{C}$.

\subsection{Apoplast extraction}

Apoplast liquid was extracted by means of vacuum infiltration (Husted and Schjoerring, 1995) modified as follows: Whole leaf laminas were infiltrated with $280 \mathrm{mM}$ sorbitol solution at a pressure of 16 bar and under vacuum for $5 \mathrm{~s}$. This procedure was repeated 5 times. After infiltration, solution on leaf surfaces was removed by use of paper towels, where upon the leaves were packed into plastic bags and left to equilibrate for $20 \mathrm{~min}$ in daylight in order to reach complete homeostasis of the apoplastic $\mathrm{NH}_{4}+$ concentration. Thereafter the leaves were centrifuged for $10 \mathrm{~min}$ at $4^{\circ} \mathrm{C}$ and $800 \mathrm{~g}$. During the night the samples were extracted in the same way as during the day, but green artificial light was used instead of white light.

Concentrations of $\mathrm{NH}_{4}^{+}$in the extracted solution were determined by flow injection analysis (FIA) or HPLC analysis (Waters Corp., Milford, USA) using o-phthalaldehyde (OPA) as reagent as described by Genfa and Dasgupta (1989). $\mathrm{pH}$ of the diluted apoplastic solution was measured with a Micro-Combination $\mathrm{pH}$ electrode (type 9810, Orion, Beverly, USA). It is assumed that the dilution with sorbitol is not changing the $\mathrm{pH}$. In order to assess cytoplasmic contamination of the apoplasts, malate dehydrogenase (E.C. 1.1.1.38) activity was determined and compared with the activity measured in bulk leaf extracts (Husted and Schjoerring, 1995). Cytoplasmic contamination was below $1.5 \%$ for all considered plant species.

\subsection{Stomatal $\mathrm{NH}_{3}$ compensation points}

The stomatal $\mathrm{NH}_{3}$ compensation point $\left(\chi_{s}, \mathrm{~mol} \mathrm{NH}_{3} \mathrm{~mol}^{-1}\right.$ air or ppbV) $\chi_{s}$, was calculated by use of Eq. (1) derived from Husted and Schjoerring (1996) taking into account that $K_{d} \ll\left[\mathrm{H}^{+}\right]_{\text {apoplast }}$ within the range of apoplastic $\mathrm{pH}$ values:

$\chi_{s}=K_{H} \cdot K_{d} \cdot \Gamma$

$\Gamma$ is the dimensionless ratio between the apoplastic $\mathrm{NH}_{4}{ }^{+}$ and $\mathrm{H}^{+}$concentrations, and $K_{H}$ and $K_{d}$ are thermodynamic constants of $10^{-1.76} 1 \mathrm{~mol}^{-1}$ and $10^{-9.25} \mathrm{moll}^{-1}$ at $25^{\circ} \mathrm{C}$, respectively. $\Gamma$ values represent a measure of the $\mathrm{NH}_{3}$ exchange potential independent of temperature

The calculated $\chi_{s}$ at $25^{\circ} \mathrm{C}\left(T_{\text {ref }}\right)$ was adjusted to the actual canopy temperature $T_{a}$ by the following equation derived from Husted and Schjoerring (1996):

$\ln \left(\frac{\chi_{s T_{a}}}{\chi_{s} T_{\mathrm{ref}}}\right)=\frac{\left(\Delta H_{\mathrm{dis}}^{0}+\Delta H_{\mathrm{vap}}^{0}\right)}{R} \cdot\left(\frac{1}{T_{\mathrm{ref}}}-\frac{1}{T_{a}}\right)$

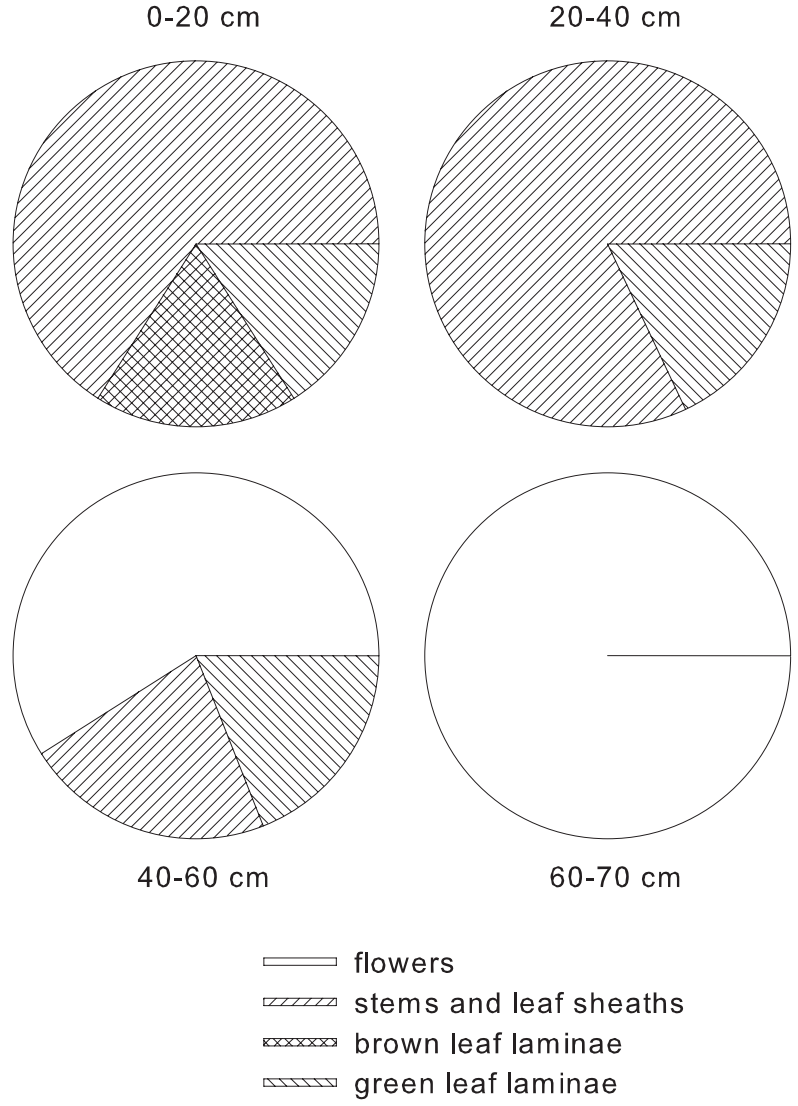

Fig. 1. Relative contribution of the fresh weight of flowers, stems and leaf sheaths, and green and brown leaf laminae to total plant biomass at different layers within the plant canopy.

$\chi_{s} T_{a}$ is the $\mathrm{NH}_{3}$ compensation point at the actual canopy temperature $T_{a}\left({ }^{\circ} \mathrm{K}\right), \Delta H_{\mathrm{dis}}^{0}$ the enthalpy of $\mathrm{NH}_{4}^{+}$dissociation $\left(52.21 \mathrm{~kJ} \mathrm{~mol}^{-1}\right), \Delta H_{\text {vap }}^{0}$ the enthalpy of vaporization $\left(34.18 \mathrm{~kJ} \mathrm{~mol}^{-1}\right)$, and $R$ the gas constant $\left(0.00831 \mathrm{~kJ} \mathrm{~K}^{-1} \mathrm{~mol}^{-1}\right)$.

Stomatal compensation points are normally expressed as dimensionless mol fraction, whereas atmospheric ammonia concentrations are expressed in this special issue as $\mu \mathrm{g} \mathrm{m}^{-3}$. Conversion of the mol fraction into concentrations is given by

$\chi\left(\frac{\mu \mathrm{g}}{\mathrm{m}^{3}}\right)=\chi\left(\frac{\mathrm{nmol}}{\mathrm{mol}}\right) \cdot 0.0409 \cdot \mathrm{MW}\left(\mathrm{NH}_{3}\right) \cdot \frac{T_{\mathrm{ref}}}{T_{a}} \cdot \frac{p_{a}}{p_{\text {ref }}}(3)$

\subsection{Determination of bulk tissue $\left[\mathrm{NH}_{4}^{+}\right]$and $\left[\mathrm{NO}_{3}^{-}\right]$}

$0.2 \mathrm{~g}$ of the frozen plant material was homogenized to powder and was extracted in $2 \mathrm{ml} 10 \mathrm{mM}$ formic acid in a cooled mortar containing a little quartz sand. The extract was centrifuged at $25000 \mathrm{~g}$ and $4^{\circ} \mathrm{C}$ for $10 \mathrm{~min}$. The supernatant was transferred to $500-\mu \mathrm{l} 0.45 \mu \mathrm{m}$ polysulphone centrifugation filters (Micro VectraSpin; Whatman Ltd., Maidstone, UK) 


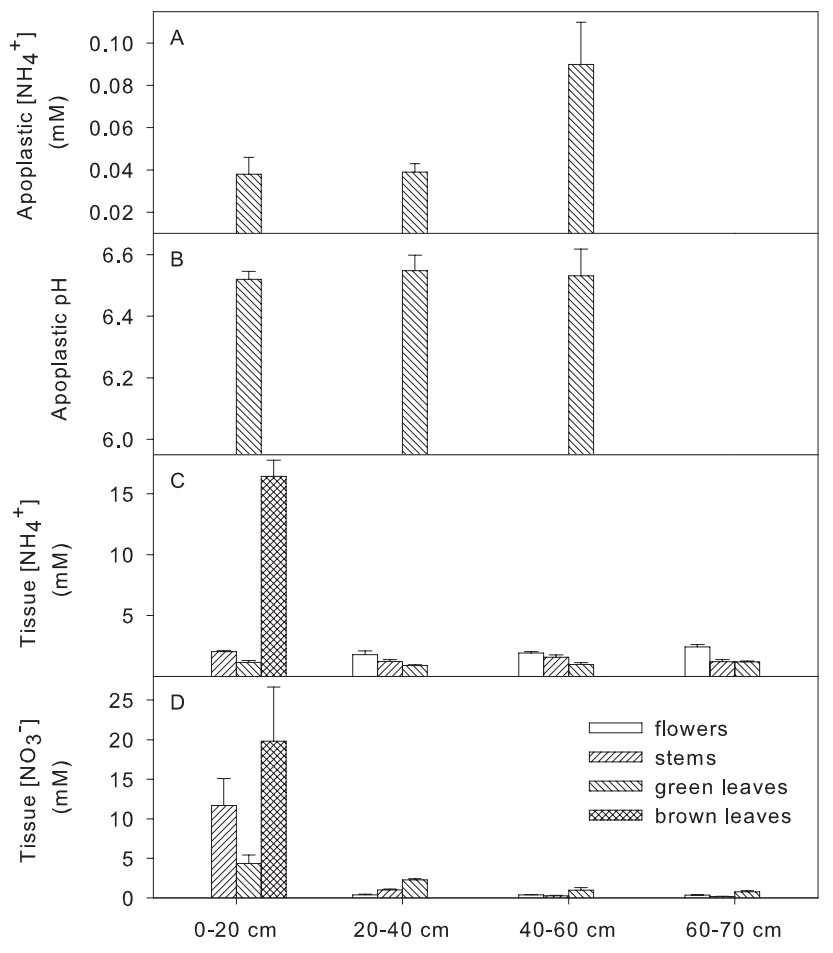

Fig. 2. Apoplastic $\left[\mathrm{NH}_{4}^{+}\right](\mathbf{A})$ and $\mathrm{pH}(\mathbf{B})$, bulk $\left[\mathrm{NH}_{4}^{+}\right](\mathbf{C})$ and $\left[\mathrm{NO}_{3}^{-}\right]$(D) of grass plants at different heights within the intact canopy on 29 May. For the highest level apoplastic data are means of the dominant species Lolium perenne and Phleum pratense weighted for species abundance $(n=8 \pm \mathrm{SE})$ whereas for the other levels a mixture of all species was considered $(n=4 \pm \mathrm{SE})$.

and spun at $5000 \mathrm{~g}$ and $4{ }^{\circ} \mathrm{C}$ for $5 \mathrm{~min}$. $\left[\mathrm{NH}_{4}^{+}\right]$and $\left[\mathrm{NO}_{3}^{-}\right]$of the supernatant was analyzed using a flow injection system (Quik Chem instrument, Lachat Instruments INC, Milwaukee, USA).

\section{Results}

\subsection{Vertical structure of $\mathrm{NH}_{3}$ exchange potential}

In order to characterise the vertical structure of $\left[\mathrm{NH}_{4}^{+}\right]$and $\left[\mathrm{NO}_{3}^{-}\right]$of the plants, plant material was collected from four different layers on the same day when the field was cut (29 May). The fully developed canopy was $76 \mathrm{~cm}$ high at that stage. Green leaf laminae, which were used for apoplast extraction, were found in all the layers except in the top level $(60-70 \mathrm{~cm})$ (Fig. 1). Brown senescent leaves constituted an additional fraction in the lowest canopy layer $(0-20 \mathrm{~cm})$, but uncontaminated apoplast liquid could not be obtained from this fraction. Apoplastic $\left[\mathrm{NH}_{4}^{+}\right]$was more than double in the leaves occurring at the upper layer of the plant compared to the lowest canopy level (Fig. 2a). Due to the relatively large variability between the replicates, the increase cannot be well quantified. Leaf apoplastic $\mathrm{pH}$ ranged between 6.3

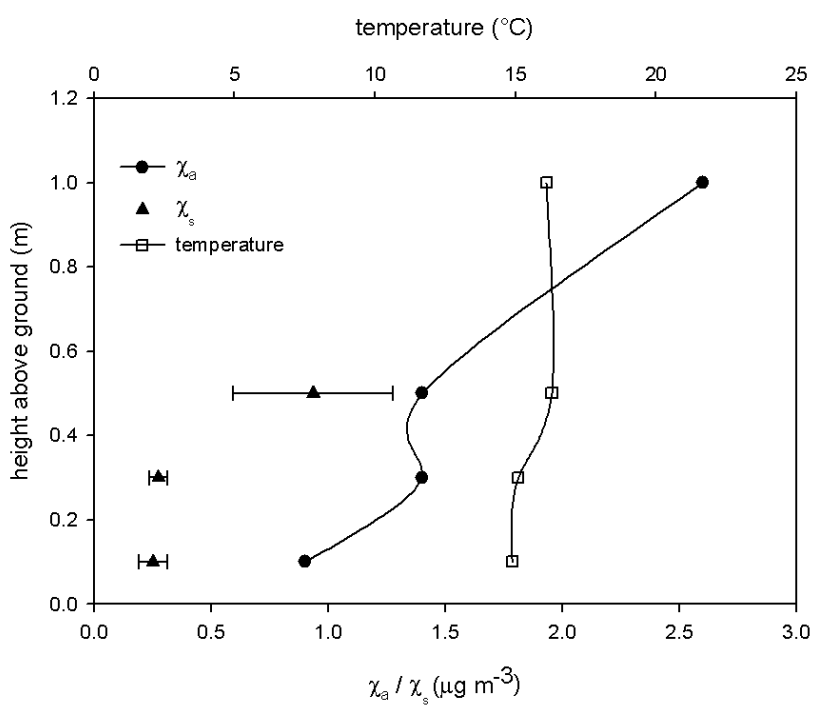

Fig. 3. $\chi_{a}$ and temperature profiles within the intact grass canopy and calculated mean $\chi_{s}$ of grass leaves on 29 May. For the highest level $\chi_{s}$ data are means of the dominant species Lolium perenne and Phleum pratense weighted for species abundance $(n=8 \pm \mathrm{SE})$ whereas for the other levels a mixture of all species was considered $(n=4 \pm \mathrm{SE}) . \chi_{a}$ represent mean concentrations over three days before cutting (10:00 a.m.-16:00 p.m.).

and 6.6 in all the layers (Fig. 2b). Tissue $\left[\mathrm{NH}_{4}^{+}\right]$was much higher in brown senescing leaves close to the soil surface compared to green leaves at the same canopy height (Fig. 2c). $\left[\mathrm{NO}_{3}^{-}\right]$of stems and green leaves decreased with canopy height (Fig. 2d) and was highest in the stems except in the layer closest to the ground where $\left[\mathrm{NO}_{3}^{-}\right]$was higher in the leaves. Similar to apoplastic $\left[\mathrm{NH}_{4}^{+}\right], \chi_{s}$ increased by a factor of two from the bottom to the top layer. Values were below the measured in-canopy $\chi_{a}$ (Fig. 3).

\subsection{Diurnal course of $\mathrm{NH}_{3}$ exchange potential}

Before the cut, the most abundant plant species Lolium perenne and Phleum pratense were selected for determination of the $\mathrm{NH}_{3}$ exchange potential during a diurnal course. The course of apoplastic $\left[\mathrm{NH}_{4}^{+}\right]$as well as $\Gamma\left(\left[\mathrm{NH}_{4}^{+}\right] /\left[\mathrm{H}^{+}\right]\right)$ in non senescent green leaves as shown for Lolium perenne in Fig. $4 \mathrm{a}$ and $\mathrm{c}$ did not show any particular pattern whereas apoplastic $\mathrm{pH}$ was higher during the night than during the day (Fig. 4b). After the field was cut, apoplastic $\left[\mathrm{NH}_{4}^{+}\right]$ of grass leaves was generally higher and a distinct diurnal course could be seen on the first day, with highest apoplastic $\left[\mathrm{NH}_{4}^{+}\right]$before noon and a decrease during the night (Fig. 4a). However, apoplastic $\left[\mathrm{NH}_{4}^{+}\right]$remained low on the following day. parallel to the lower canopy temperature on the second day compared to the day before. However, the increase in $\left[\mathrm{NH}_{4}^{+}\right]$following the cut was more pronounced in the leaf tissue and was also observed on the second day (Fig. 5a). In 


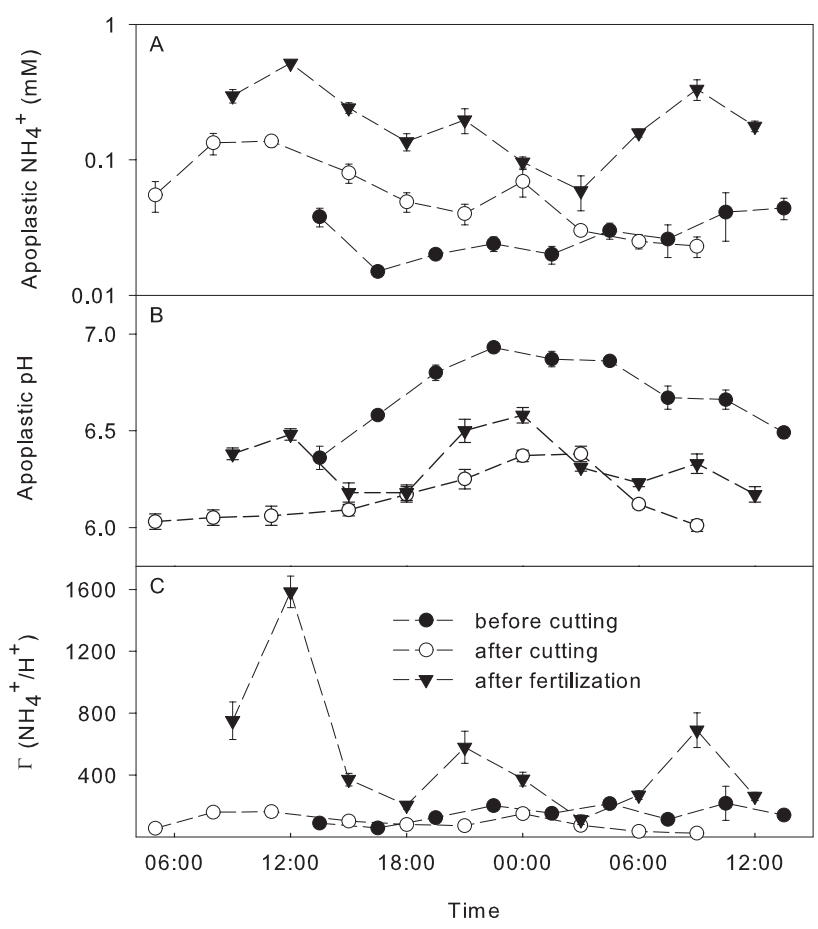

Fig. 4. Diurnal course of apoplastic $\left[\mathrm{NH}_{4}^{+}\right]$(A), apoplastic $\mathrm{pH}$ (B) and $\Gamma$ (apoplastic $\mathrm{NH}_{4}^{+} / \mathrm{H}^{+}$) $(\mathbf{C}$ ) in grass leaves before and after cutting and after fertilization. Data are means of 4 replicates \pm $\mathrm{SE}$ and represent a mixture of all species except before fertilization when data represent the most dominant species Lolium perenne.

contrast, $\left[\mathrm{NO}_{3}^{-}\right]$seemed to decrease during the day and an increase was observed during the night (Fig. 5b). Like before the cut, highest apoplastic $\mathrm{pH}$ was measured in the night (Fig. 4b). Due to generally lower apoplastic $\mathrm{pH}$ of the cut grass mix compared to the grass before cutting $\Gamma$ was similar before and after the cut (Fig. 4c). After fertilization $\left[\mathrm{NH}_{4}^{+}\right]$ increased in both the apoplast and the tissue (Figs. 4a and 5a). The diurnal pattern in apoplastic $\left[\mathrm{NH}_{4}^{+}\right]$and $\Gamma$ was more pronounced after $\mathrm{N}$ application than before. Before fertilization a relatively good correlation was seen between leaf tissue and apoplastic $\left[\mathrm{NH}_{4}^{+}\right]$, which was significant $(p<0.01)$ after cutting but not before cutting (Fig. 6). Because apoplastic $\left[\mathrm{NH}_{4}^{+}\right]$increased while tissue $\left[\mathrm{NH}_{4}^{+}\right]$was rather unaffected after fertilization, the correlation between tissue and apoplastic $\left[\mathrm{NH}_{4}^{+}\right]$was very low.

Before the field was cut the vertical profile of $\chi_{a}$ was predominantly characterised by decreasing $\chi_{a}$ towards the ground as shown for a diurnal course in Fig. 7. This $\chi_{a}$ profile would therefore indicate $\mathrm{NH}_{3}$ deposition from the atmosphere to the plant canopy. Calculated $\chi_{s}$ of both Lolium perenne and Phleum pratense, which corresponded to the upper two $\chi_{a}$ measuring heights, were below the in-canopy $\chi_{a}$. The increase in $\chi_{a}$ during the night was not reflected in $\chi_{s}$. An inverse $\chi_{a}$ profile was observed after the canopy had been cut. At the lowest measuring height $\chi_{a}$ reached

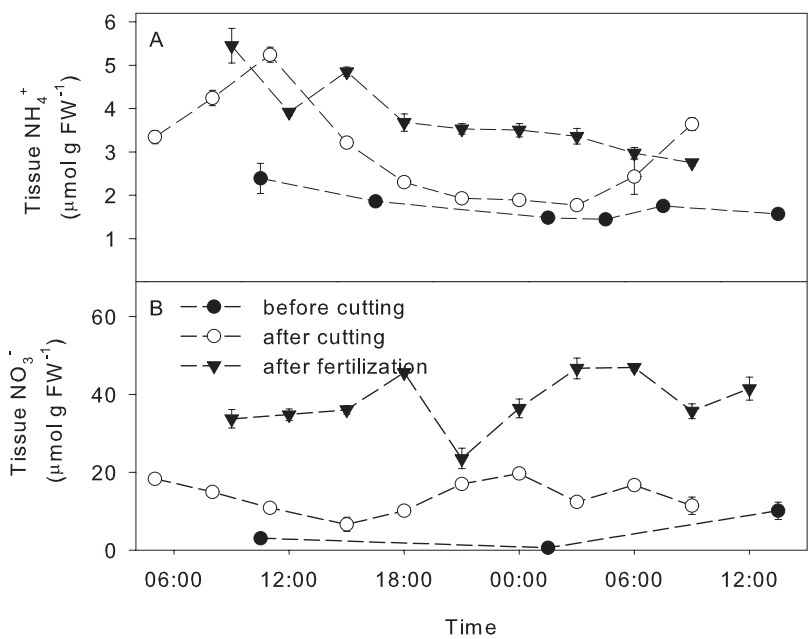

Fig. 5. Diurnal course of bulk $\left[\mathrm{NH}_{4}^{+}\right](\mathbf{A})$ and $\left[\mathrm{NO}_{3}^{-}\right](\mathbf{B})$ in grass leaves before and after cutting and after fertilization. Data are means of 4 replicates $\pm \mathrm{SE}$ and represent a mixture of all species.

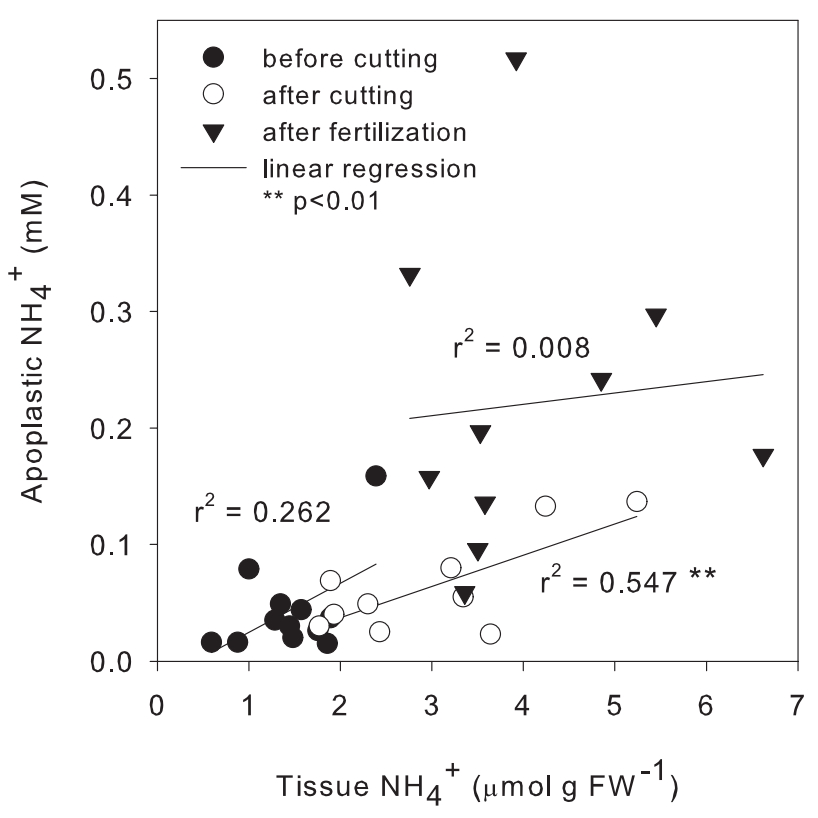

Fig. 6. Correlation between mean bulk leaf $\left[\mathrm{NH}_{4}^{+}\right]$and $\Gamma$ (apoplastic $\mathrm{NH}_{4}^{+} / \mathrm{H}^{+}$) in leaves of a grass mixture during a diurnal course before and after cutting and after fertilization.

** Significance at $p<0.01$.

$10 \mu \mathrm{g} \mathrm{m}^{-3}$ in the morning and $\chi_{a}$ decreased with measuring height (Fig. 8). $\chi_{a}$ was lower during the night than during the day. Accordingly, highest $\mathrm{NH}_{3}$ emission was measured during the day (Milford et al., 2008). Generally, $\chi_{s}$ of the cut grass were much lower than $\chi_{a}$ above the plant canopy. The same direction of the slope of the vertical $\chi_{a}$ gradient but higher concentrations during the day was seen after $\mathrm{N}$ application (Fig. 9). A typical diurnal pattern with highest 


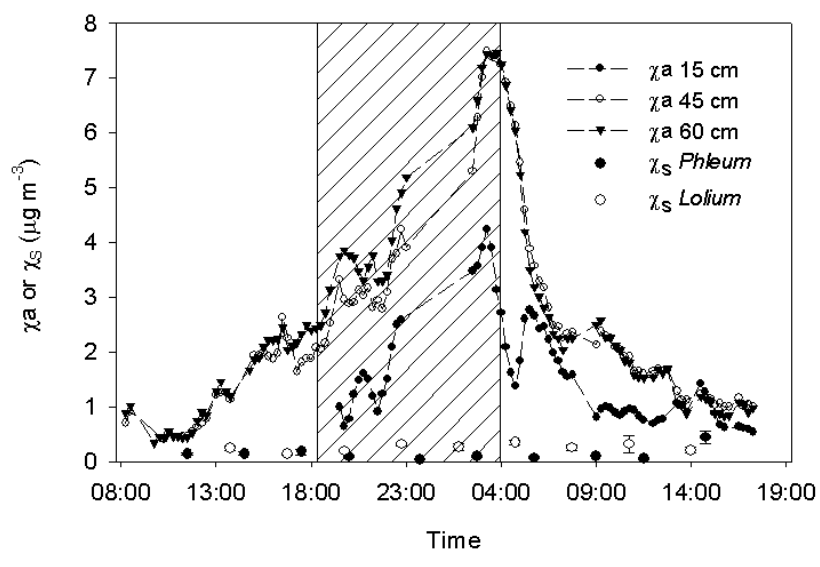

Fig. 7. Diurnal course of $\mathrm{NH}_{3}$ flux above the plant canopy (A), incanopy $\left[\mathrm{NH}_{3}\right]$ gradient and calculated $\chi_{s}$ for the dominant grass species Lolium perenne and Phleum pratense (B) before cutting (26/27 May). The height of the canopy was $70 \mathrm{~cm}$ at this stage. $\chi_{s}$ are means of 4 replicates \pm SE. The dark period is indicated by the shaded area.

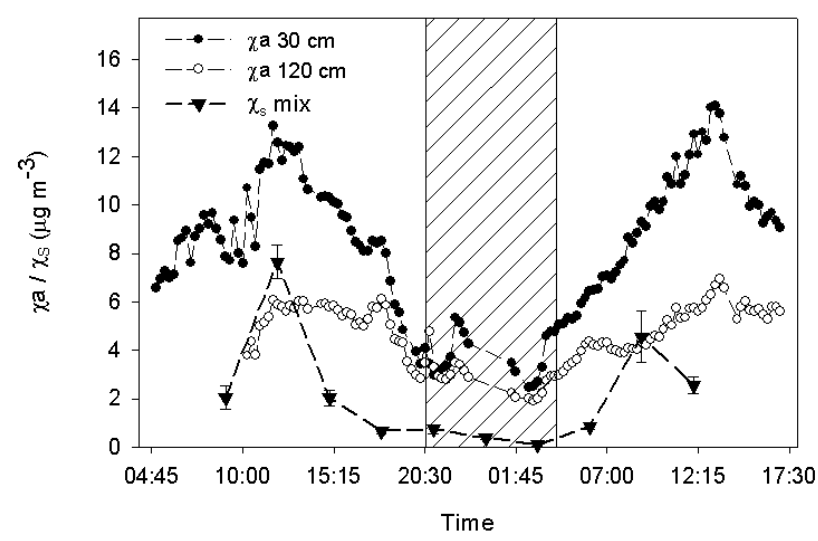

Fig. 8. Diurnal $\chi_{a}$ gradient above the canopy and calculated $\chi_{s}$ for grass stubbles after cutting and prior to fertilization (4/5 June). $\chi_{s}$ are means of 4 replicates \pm SE. The dark period is indicated by the shaded area.

concentration around noon was most pronounced after fertilization and was reflected in both calculated $\chi_{s}$ and atmospheric $\chi_{a}$. Although $\chi_{s}$ of the fertilized grass were about five times higher than before fertilization the values were still below atmospheric $\chi_{a}$ of the lowest measuring height during the whole diurnal course.

\section{Discussion}

Application of the vacuum infiltration technique directly in the field enabled an immediate extraction of apoplast liquid and therefore frequent determination of the $\mathrm{NH}_{3}$ exchange potential of the plants during a diurnal course. The measured apoplastic $\mathrm{NH}_{4}^{+}$levels before fertilization were about $0.1 \mathrm{mM}$ (Fig. 4a) matching values reported in pastures

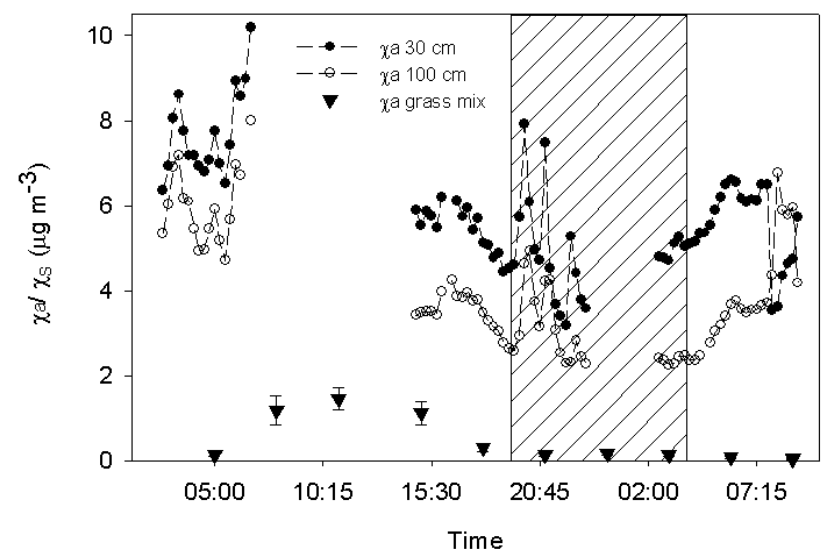

Fig. 9. Diurnal $\chi_{a}$ gradient above the canopy and calculated $\chi_{s}$ for grass stubbles 7 days after fertilization (12/13 June). $\chi_{s}$ are means of 4 replicates \pm SE. The dark period is indicated by the shaded area.

under similar $\mathrm{N}$ conditions by Herrmann et al., 2001 and (Loubet et al., 2002. Considerably higher apoplastic $\mathrm{NH}_{4}^{+}$ concentrations, 0.2 to $0.9 \mathrm{mM}$, were observed in an intensively managed grassland in The Netherlands throughout the growing season (van Hove et al., 2002). The nitrogen availability in the soil, particularly that of ammonium, has a profound influence on apoplastic $\mathrm{NH}_{4}^{+}$concentrations as also demonstrated by the increase following fertilization (Fig. 4a) (Mattson et al., 2008).

Determination of apoplastic $\left[\mathrm{NH}_{4}^{+}\right]$and $\mathrm{pH}$ is a labour intensive analysis. Consequently the analysis of the diurnal structure and the analysis of the vertical profiles were performed on different days. In the following discussion we assume that the determined values are representative for the grass canopy for the days before the cut. The vertical profile was measured in a remaining uncut plot on the same day as the rest of the field was cut. For the comparison with the atmospheric $\mathrm{NH}_{3}$ in canopy concentration the mean values of them of the previous three days during daytime (10:00 16:00) have been taken and are shown in Fig. 3.

Apoplastic $\left[\mathrm{NH}_{4}^{+}\right]$and $\chi_{s}$ increased by a factor of two from the bottom to the top of the intact plant canopy (Figs. 2a and 3). Thus, young leaves had a relatively high $\mathrm{NH}_{3}$ emission potential. At all in-canopy levels considered, $\chi_{s}$ was below the measured atmospheric $\chi_{a}$, indicating that plants acted as $\mathrm{NH}_{3}$ sinks. This was confirmed by the measured $\mathrm{NH}_{3}$ flux which was characterized by $\mathrm{NH}_{3}$ deposition (see Milford et al., 2008) and is in agreement with measurements carried out over a grass/clover canopy (Herrmann et al., 2001).

After the cut the apoplastic $\left[\mathrm{NH}_{4}^{+}\right]$decreased on the second day (Fig. 4) in parallel with the canopy temperature. This points to a temperature dependent physiological control of the apoplastic $\left[\mathrm{NH}_{4}^{+}\right]$, because lower temperature would be in favour of higher apoplastic $\left[\mathrm{NH}_{4}^{+}\right]$assuming constant production. 
The $\mathrm{NH}_{3}$ emission measured from the field after the cut (see Milford et al., 2008) could not be totally explained by a rise in $\chi_{s}$ of the cut grass. $\chi_{s}$ of the senescent plant material either attached to the stubbles or lying on the ground, however, could not be calculated since apoplastic infiltration of senescent plant material could not be achieved. Yet, very high tissue $\left[\mathrm{NH}_{4}^{+}\right]$measured in plant litter, which accounted for about $20 \%$ of the total above ground biomass after the cut, indicate that this fraction may represent an important $\mathrm{NH}_{3}$ source. This might explain the $\mathrm{NH}_{3}$ emission measured after cutting, when the litter fraction was not covered by a canopy and no re-capture by the intact leaves could occur anymore. Husted et al. (2000) showed that in an oilseed rape field, the plant litter fraction represented an $\mathrm{NH}_{3}$ source, while intact leaves acted as $\mathrm{NH}_{3}$ sinks. Similarly, in a grass/clover crop the highest in-canopy $\chi_{a}$ was found towards the soil surface (Denmead et al., 1976). In the present investigation atmospheric $\mathrm{NH}_{3}$ could not be measured below $15 \mathrm{~cm}$ and therefore $\mathrm{NH}_{3}$ concentration directly above the soil surface is not known. However, using a tissue $\left[\mathrm{NH}_{4}^{+}\right]$value for brown leaves as presented in Fig. 2c and a measured $\mathrm{pH}$ of 7 (data not shown) would result in $\Gamma$ values for the litter of about 5000. Although this $\Gamma$ value cannot be considered as a direct measure of the effective $\mathrm{NH}_{3}$ emission of plant litter it still indicates a high potential for $\mathrm{NH}_{3}$ emission. Furthermore, $\mathrm{NH}_{3}$ flux measurements carried out in a climate chamber study revealed a $\mathrm{NH}_{3}$ emission of about $170 \mathrm{ng} \mathrm{m}^{-2}$ leaf area $^{s-1}$ from cut senescent leaf material of Lolium perenne (Mattsson and Schjoerring, 2003). This would result in a $\mathrm{NH}_{3}$ emission of about $80 \mathrm{ng} \mathrm{m}^{-2} \mathrm{~s}^{-1}$ using the amount of litter biomass per surface area of $20 \%$ of total as measured in the present investigation. While plant litter emission could explain the measured $\mathrm{NH}_{3}$ emission after the cut it cannot entirely account for the high emission observed after fertilization. Directly after $\mathrm{N}$ application most of the $\mathrm{NH}_{3}$ emission most probably originated from fertilizer particles lying on the ground (Herrmann et al., 2001). Yet, the $\mathrm{NH}_{3}$ emission measured over the following days and its distinct diurnal pattern indicate that another $\mathrm{NH}_{3}$ source than fertilizer must be involved. Although $\chi_{s}$ of the grass considerably increased after fertilization (Fig. 4c) it still remained below measured atmospheric $\chi_{a}$ and thus plants should represent an $\mathrm{NH}_{3}$ sink.

A discrepancy between micrometeorological or cuvette studies and the bioassay approach in estimating $\chi_{s}$ has been observed in several investigations. In most of these studies the bioassay approach yielded smaller estimates of $\chi_{s}$ compared to the micrometerological or cuvette measurements (Mattsson et al., 1997; Hill et al., 2001; Mattsson and Schjoerring, 2002). Non stomatal exchange might be a reason for the observed discrepancies. Bioassay studies are a measure for the equilibrium $\mathrm{NH}_{3}$ concentration in the stomatal cavity, whereas micrometeorological and cuvette measurements are indicating the $\mathrm{NH}_{3}$ concentration in the surrounding atmosphere of the plants
Considering a possible underestimation of $\chi_{s}$ in the present study, $\mathrm{NH}_{3}$ emission from the plants would become likely, especially after cutting and fertilization around midday, when the ratio between $\chi_{a}$ and estimated $\chi_{s}$ was smaller than during the rest of the day. However, the discrepancy between $\chi_{a}$ and estimated $\chi_{s}$ was still considerable for most of the collected data, indicating that also after fertilization other $\mathrm{NH}_{3}$ sources might be involved in the $\mathrm{NH}_{3}$ exchange of the canopy.

The diurnal measurements clearly showed that apoplastic $\left[\mathrm{NH}_{4}^{+}\right]$may change during the course of the day, with highest values around midday and decreasing concentrations during the night. This pattern was also reflected in $\Gamma$ which is an indicator for the $\mathrm{NH}_{3}$ exchange potential of a plant but in contrast to $\chi_{s}$, it is independent of any change in canopy temperature. This is different from observations made in an oilseed rape field, where no diurnal variation in $\Gamma$ existed and where canopy temperature was the only factor influencing $\chi_{s}$ on a diurnal scale (Husted et al., 2000).

Before fertilization a relatively clear linear relationship existed between leaf tissue $\left[\mathrm{NH}_{4}^{+}\right]$and apoplastic $\mathrm{NH}_{4}^{+}$(Fig. 6), but this was not the case after fertilization. In addition, the ratio between tissue $\left[\mathrm{NH}_{4}^{+}\right]$and apoplastic $\left[\mathrm{NH}_{4}^{+}\right]$was much lower after fertilization compared to before fertilization. These findings differ from studies in a Scottish grassland, where the magnitude of increase in $\left[\mathrm{NH}_{4}^{+}\right]$after cutting was similar for the apoplastic and bulk tissue fraction (Loubet et al., 2002). Also in two grass species grown with different $\mathrm{N}$ supply the correlation between apoplast and leaf tissue $\left[\mathrm{NH}_{4}^{+}\right]$was fairly good (Mattsson and Schjoerring, 2002) while in a wild perennial the same correlation was poor (Hill et al., 2002). The data presented here indicate that $\left[\mathrm{NH}_{4}^{+}\right]$ in the tissue and in the apoplast may be regulated independently and thus the tissue $\left[\mathrm{NH}_{4}^{+}\right]$can not always be used as an indicator of $\chi_{s}$.

\section{Conclusions}

From the present investigation we conclude that the plants of a fully developed grassland acted as $\mathrm{NH}_{3}$ sinks and that $\mathrm{NH}_{3}$ was predominantly deposited to the tall canopy. $\mathrm{NH}_{3}$ emission measured after the cut and after fertilization could not entirely be accounted for by stomatal loss. Yet, elevated tissue $\left[\mathrm{NH}_{4}^{+}\right]$and high $\Gamma$ values in especially senescent plant material indicated that $\mathrm{NH}_{3}$ might be emitted from plant litter, which could explain the $\mathrm{NH}_{3}$ emission measured after cutting. Although Mattsson et al. (2008) showed a high inter-species correlation between $\Gamma$ and bulk leaf $\left[\mathrm{NH}_{4}^{+}\right]$, this comparison shows that there are limitations in this relationship when considering temporal differences for individual species. Specifically, the relationship was shown to change after fertilization, indicating that bulk tissue [NH4+] should only be used as an indicator of $\Gamma$ when calibration specific to current conditions is available.

Edited by: K. Pilegaard 


\section{References}

Burkhardt, J., Flechard, C. R., Gresens, F., Mattsson, M. E., Jongejan, P. A. C., Erisman, J. W., Weidinger, T., Meszaros, R., Nemitz, E., and Sutton, M. A.: Modeling the dynamic chemical interactions of atmospheric ammonia and other trace gases with measured leaf surface wetness in a managed grassland canopy, Biogeosciences Discuss., 5, 2505-2539, 2008,

http://www.biogeosciences-discuss.net/5/2505/2008/.

Bussink, D. W., Lowry, A., Harper, A., and Corré, W. J.: Ammonia transport in a temperate grassland: 1l. Diurnal fluctuations in response to weather and management conditions, Agron. J., 88, 621-626, 1996.

David, M., Roche, R., Mattsson, M., Sutton, M. A., Schjoerring, J. K., Daemmgen, U., and Cellier, P.: Analysis of ammonia fluxes with intensively managed grassland using dynamic chambers 11 . The effect of management options, Biogeosciences Discuss., in press, 2008.

Denmead, O. T., Freney, J. R., and Simpson, J. R.: A closed ammnonia cycle within a plant canopy, Soil Biol. Biochem., 8, 161164, 1976.

Farquhar, G. D., Firth, P. M., Wetselaar, R., and Weir, B: On the gaseous exchange of ammonia between leaves and the environment: determination of the ammonia compensation point, Plant Physiol., 66, 710-714, 1980.

Flechard, C. R., Fowler, D., Sutton, M. A., and Cape, J. N.: A dynamic chemical model of bi-directional ammonia exchange between semi-natural vegetation and the atmosphere, Q. J. Roy. Meteor. Soc., 125, 2611-2641, 1999.

Genfa, Z. and Dasgupta, P. K.: Fluorometric measurement of aqueous ammonium ion in a flow injection system, Anal. Chem., 61, 408-412, 1989.

Harper, L. A., Bussink ,D. W., van der Meer, H. G., and Corré, W. J.: Ammonia transport in a temperate grassland: 1. Seasonal transport in relation to soil fertility and crop management, Agron. J., 88, 614-621, 1996.

Herrmann, B., Jones, S. K., Fuhrer, J., Feller, U., and Neftel, A.: N budget and $\mathrm{NH}_{3}$ exchange of a grass/clover crop at two levels of N application, Plant and Soil, 235, 243-252, 2001.

Hill, P., Raven, J. A., Loubet, B., Fowler, D., and Sutton, M. A.: Comparison of gas exchange and bioassay determinations of the ammonia compensation point in Luzula sylvatica, (Huds.) Gaud. Plant Physiol., 125, 476-487, 2001.

Hill, P. W., Raven, J. A., and Sutton, M. A.: Leaf age-related differences in apoplastic $\mathrm{NH}_{4}^{+}$concentration, $\mathrm{pH}$ and the $\mathrm{NH}_{3}$ compensation point for a wild perennial, J. Exp. Bot., 53, 277-286, 2002.

Horvath, L., Astalos, M., Fuhrer, E., Meszaros, R., and Weidinger, T.: Measurement of ammonia exchange over grassland in the Hungarian Great Plain, Agric. Forest Meteorol., 130, 282-298, 2005.

Husted, S. and Schjoerring, J. K.: Apoplastic pH and ammonium concentration in leaves of Brassica napus L., Plant Physiology, 190, 1453-1460, 1995.

Husted, S., Mattsson, M., and Schjoerring, J. K.: Ammonia compensation points in two cultivars of Hordeum vulgare L., during vegetative and generative growth, Plant, Cell Environ., 19, 12991306, 1996.

Husted, S. and Schjoerring, J. K.: Ammonia flux between oilseed rape plants and the atmosphere in response to changes in leaf temperature, light intensity and air humidity, Plant Physiol., 112, 67-74, 1996.

Husted, S., Schjoerring, J. K., Nielsen, K. H., Nemitz, E., and Sutton, M. A.: Stomatal compensation points for ammonia in oilseed rape plants under field conditions, Agric. Forest Meteorol., 105, 371-383, 2000.

Husted, S., Mattsson, M., Möllers, C., Wallbraun, M., and Schjoerring, J. K.: Photorespiratory $\mathrm{NH}_{4}^{+}$production in leaves of wildtype and GS2-antisense oilseed rape, Plant Physiol., 130, 989998, 2002.

Kruit, R., Erismann, J. W., van Pul, W. A. J., Otjes, R. P., Hofschreuder, P., Jacobs, A. F. G., and Holtslag, A. M.: Ammonia fluxes and derived canopy compensation points over nonfertilized agricultural grassland in The Netherlands using the new gradient ammonia-high accuracy-monitor (GRAHAM), Atmos. Environ., 41, 1275-1287, 2007.

Lemon, E. and van Houtte, R.: Ammonia exchange at the land surface, Agron. J., 72, 876-883, 1980.

Loubet, B., Milford, C., Hill, P. W., Tang, Y. S., Cellier, P, and Sutton, M. A.: Seasonal variability of apoplastic $\mathrm{NH}_{4}^{+}$and $\mathrm{pH}$ in an intensively managed grassland, Plant Soil, 238, 97-110, 2002.

Mattsson, M., Häusler, R. E., Leegood, R. C., Lea, P. J., and Schjoerring, J. K.: Leaf-atmosphere $\mathrm{NH}_{3}$ exchange in barley mutants with reduced activities of glutamine synthetase, Plant Physiol., 114, 1307-1312, 1997.

Mattsson, M., Husted, S., and Schjoerring, J. K.: Influence of nitrogen nutrition and metabolism on ammonia volatilization in plants, Nutr. Cycl. Agroecosys., 51, 35-40, 1998.

Mattsson, M. and Schjoerring, J. K.: Dynamic and steady state responses of inorganic nitrogen pools and $\mathrm{NH}_{3}$ exchange in leaves of Lolium perenne and Bromus erectus to changes in root supply, Plant Physiol., 128, 742-750, 2002.

Mattsson, M. and Schjoerring, J. K.: Senescence-induced changes in apoplastic and bulk tissue ammonia concentrations of ryegrass leaves, New Phytol., 160, 489-499, 2003.

Mattsson, M., Herrmann, B., Jones, S., Neftel, A., Sutton, M. A., and Schjoerring, J. K.: Contribution of different grass species to plant-atmosphere ammonia exchange in intensively managed grassland, Biogeosciences Discuss., 5, 2583-2605, 2008a, http://www.biogeosciences-discuss.net/5/2583/2008/.

Mattsson, M., Herrmann, B., David, M., Loubet, B., Riedo, M., Theobald, M. R., Sutton, M. A., Bruhn, D., Neftel, A., and Schjoerring, J. K.: Temporal variability in bioassays of ammonia exchange potential in relation to plant and soil nitrogen parameters in intensively managed grassland, Biogeosciences Discuss., 5, 2749-2772, 2008b, http://www.biogeosciences-discuss.net/5/2749/2008/.

Milford, C., Theobald, M. R., Nemitz, E., Hargreaves, K. J., Horvath, L., Raso, J., Dämmgen, U., Neftel, A., Jones, S. K., Hensen, A., Loubet, B., Cellier, P., and Sutton, M. A.: Ammonia fluxes in relation to cutting and fertilization of an intensively managed grassland derived from an inter-comparison of gradient measurements, Biogeosciences Discuss., 5, 4699-4744, 2008, http://www.biogeosciences-discuss.net/5/4699/2008/.

Neftel, A., Blatter, A., Gut, A., Högger, D., Meixner, F., Ammann, C., and Nathaus, F. J.: $\mathrm{NH}_{3}$ soil and soil surface gas measurements in a triticale wheat field, Atmos. Environ., 32, 499-505, 1998.

Nemitz, E., Sutton, M. A., Gut, A., San José, R., Husted, S., and 
Schjoerring, J. K.: Sources and sinks of ammonia within an oilseed rape canopy, Agric. For. Meteorol. (Ammonia Special Issue), 105(4), 385-404, 2000.

Sharpe, R. R. and Harper, L. A.: Soil, plant and atmospheric conditions as they relate to ammonia volatilization, Fert. Res., 42, 149-158, 1995.

Sommer, S. G., Schjoerring, J. K., and Denmead, O. T.: Ammonia emission from mineral fertilizers and fertilized crops, Adv. Agron., 82, 557-622, 2004.

Sutton, M. A., Fowler, D., Moncrieff, J. B., and Storeton-West, R. L.: The exchange of atmospheric ammonia with vegetated surfaces, II. Fertilized vegetation, Q. J. Roy. Meteor. Soc., 119, 1047-1070, 1993.

Sutton, M., Schjoerring, J. K., and Wyers, P.:: Plant-atmosphere exchange of ammonia, Phil. Trans. R. Soc. London, 351, 261278, 1995.

Sutton, M. A., Nemitz, E. , Erisman ,J. W., Beier, C., Bahl, K. B., Cellie, P., de Vries, W., Cotrufo, F., Skiba, U., Di Marco, C., Jones, S., Laville, P., Soussana, J. F., Loubet, B., Twigg, M., Famulari, D., Whitehead, J., Gallagher, M. W., Neftel, A., Flechard, C. R., Herrmann, B., Calanca, P. L., Schjoerring, J. K., Daemmgen, U., Horvath, L., Tang, Y. S., Emmett, B. A., Tietema, A., Penuelas, J., Kesik, M., Brueggemann, N., Pilegaard, K., Vesala, T., Campbell, C. L., Olesen, J. E., Dragosits, U., Theobald, M. R., Levy, P., Mobbs, D. C., Milne, R., Viovy, N., Vuichard, N., Smith, J. U., Smith, P., Bergamaschi, P., Fowler, D., and Reis, S.: Challenges in quantifying biosphere-atmosphere exchange of nitrogen species, Environ. Pollut., 150, 125-139, 2007.
Sutton, M. A., Nemitz, E., Theobald, M. R., Milford, C., Dorsey, J. R., Gallagher, M. W., Hensen, A., Jongejan, P. A. C., Erisman, J. W., Mattsson, M. E., Schjoerring, J. K., Cellier, P., Loubet, B., Roche, R., Neftel, A., Hermann, B., Jones, S., Lehman, B. E., Horvath, L., Weidinger, T., Rajkai, K., Burkhardt, J., Löpmeier, F. J., and Daemmgen, U.: Dynamics of ammonia exchange with cut grassland: strategy and implementation of the GRAMINAE Integrated Experiment, Biogeosciences Discuss., 5, 3347-3407, 2008 , http://www.biogeosciences-discuss.net/5/3347/2008/.

Trebs, I., Lara, L. L., Zeri, L. M. M., Gatti, L. V., Artaxo, P., Dlugi, R., Slanina, J., Andreae, M. O., and Meixner, F. X.: Dry and wet deposition of inorganic nitrogen compounds to a tropical pasture site (Rondônia, Brazil), Atmos. Chem. Phys., 6, 447-469, 2006, http://www.atmos-chem-phys.net/6/447/2006/.

van Hove, L. W. A., Heeres, P., and Bossen, M. E.: The annual variation in stomatal ammonia compensation point of rye grass (Lolium perenne L.) leaves in an intensively managed grassland, Atmos. Environ., 36, 2965-2977, 2002.

Walker, J. T., Robarge, W. P., Wu, Y., and Meyers, T.: Measurement of bi-directional ammonia fluxes over soybean using the modified Bowen-ratio technique, Agr. Forest Meteorol., 138, 54-68, 2006. 